\title{
AN EMPIRICAL STUDY ON THE FACTORS AFFECTING ONLINE RETAIL BRAND ENGAGEMENT AND PURCHASE INTENTION
}

\author{
SUBHAJIT BHATTACHARYA \\ Department of Marketing Management \\ Xavier Institute of Social Service \\ VIJETA ANAND \\ Jharkhand Rai University
}

\begin{abstract}
The Consumer buying criterion has reformed massively in this present digitized marketing environment. The growing importance \& popularity of online buying is very much substantial and quite evident in India these days. This study attempts to investigate the relationships between brand trust, social linkages, brand awareness, online retail brand engagement and final brand selection \& purchase intention. The current research also examined the linkages among brand trust, social linkages, brand awareness and online retail brand engagement and in creating the final brand selection \& purchase intention relating to Indian online retail market. Data from 252 observations were analyzed using the structural equation modeling method. The outcome of this research paper shows how an effective online retail brand engagement environment can be created to boost the final brand selection \& purchase intention in the Indian online market place.
\end{abstract}

Keywords: Online shopping behaviour, online buying experience, online trust, social linkages, online retail brand engagement

\section{Introduction}

The present digitized world is creating good opportunities to the seller to reach customers much faster, easier and in economic ways (Kim, 2012).Digital marketing has proved to be a blessing for e-retailing companies as business has become more user friendly \& very innovative as well as interactive at the same time. The changing scenario of marketing as a whole has made online buying more acceptable these days for new age customers. According to UCLA Centre for Communication Policy (2001) online shopping is the third most popular activity over the Internet, immediately after e-mail using/ instant messaging activity and web browsing. If we consider the case of Amazon then it can be observed that it has sold 36.8 million items in 2013 which is significantly $38.9 \%$ higher than the previous year, with a record braking achievement of about 426 products sold per second during Christmas 2013. As per the study of McKinsey \& Company (December 2012) named "Online and Upcoming: The Internet's Impact on India" it can be observed that the internet users in India has crossed 120 million in the year 2012 which is presently the third-largest in the world. The study has also forecasted that India is likely to have the second-biggest consumer base in the world, and the largest in terms of achieving incremental growth, with 330 million to 370 million Internet users in year 2015. According to statista.com (The Statistics Portal) it can be observed that the worldwide B2C e-commerce sales was 1.058 trillion in 2012 and the organisation has also forecasted that in 2016 global B2C e-commerce sales is likely to reach 1.92 trillion U.S. dollars. As per 
Google India Study reports (January, 2013), approximately 8 million Indians have shopped online in 2012. The report has also indicated the growth of $128 \%$ in between year 2011 to 2012 which is significantly higher in comparison to the $40 \%$ growth in 2010 to 2011 . According to the research report by Mckinsey \& company (2013) named iConsumers:Life online (A Report on Telecommunication Media and Technology) has revealed that the youth segment is one of the growing \& potential segment for online buying and their preference is buying books, electronic items, computer accessories and apparels. Another latest study by the leading global research agency Forrester (May1,2015), indicate that e-commerce market in India is set to grow at an alarming rate within the AsiaPacific Region at a compound annual growth rate of more than $51 \%$ over the next five years as more Indian consumers have started purchasing online, especially via mobile devices. The report has also revealed that there is a huge potential of increasing the number of online buyers and the per capita online spending in the days to come. This market is gaining more popularity in modern times; the global brands are also looking at this market's growth and also trying to be benefitted from the long-term potential of online retailing. The study has also indicated that India will be the fastest growing E-Commerce Market in Asia-Pacific region with an expected growth of US\$ 8.8 Billion by 2016 .

In the Indian context online buying is the latest trend. The growing importance \& popularity of online buying is very much substantial \& quite evident in India these days. This research article seeks to contribute in the domain of online marketing and consumer behaviour analysis relation to online retail brand engagement. The present research propounds an original and innovative framework of exploring the process to create higher consumer brand engagement at Indian online marketplace by triggering the socio-emotional linkages to gain competitive advantage to motivate the potential online buyers for final brand selection. The constructs or the factors that are being taken in to account in this present research article are namely: Brand Trust, Social Linkages, Brand-awareness, Online
Retail Brand Engagement and Final Brand Selection and Purchase Intention.

The paper is organized as follows. First an overview of online buying pattern of the consumer, how online buying is influenced by multiple factors and driving forces are discussed. Then the study of the existing literature with regards to online consumer behaviour and branding aspect, followed by objective of the study are presented There after the research methods and data analysis are described Finally the outcomes, discussions, managerial implications \& scope for future research are discussed.

\section{Literature Review and Conceptualization}

Online shopping is a remote based transaction or exchange (Comegys, Hannula \& Väisänen, 2009; Poddar, Mosteller \& Ellen, 2009). Consumers who are buying online are unable to use or consume the product instantly as they have to wait for product delivery (Ryan \& Valverde, 2005), but positive consumer experiences in online marketplace motivates the online buyers (Verhagen \& Van Dolen, 2011; Kim, 2012). Online consumer experiences (OCEs) is connected with the psychological and emotional framework of any consumers when interacting with online products and brands $(\mathrm{Li}$, Daugherty \& Biocca, 2001). Earlier studies have recommended that OCEs may have positive persuasion effects (Rose, Hair \& Clark, 2011). Online buying is relatively new as compared to home shopping; the positive home purchasing experience (shopping via catalogue, telephone, or television, for example) have a significant \& encouraging effect on online buying (Swinyard \& Smith, 2003; Forsythe \& Shi, 2003). Several empirical studies have illustrated, that now a days, many individuals have an inclination to start their shopping process with a proper information search on the Internet before they move to the retail store (Ward \& Margonasky, 2002). The Internet offers easy and rapid assessment of different types of products. Internet has brought enormous changes in the shopping and buying environment (Varadarajan \& Yadav, 2002). It 
has opened up the platform for accessing the data and information on the basis of consumers' choice. The purchase decision of the consumers has become more effective and on the other hand marketers are also benefited in the gathering of consumer data from the internet (Bhatnagar $\&$ Ghose, 2004). People who are connected to e-shopping may have to face the financial risk because of credit card misuse (Forsythe \& Shi, 2003) but this is proven as a perceptual risk. To counter this specific financial risk COD (Cash on Delivery) option in payment has escalated the popularity of e-shopping or online shopping. Other researchers have talked about two types of uncertainty in an online buying context that are system-dependent and transaction-specific (McCole, Ramsey \& Williams, 2009). Security concerns are mostly related with the former while confidentiality concerns are associated with the latter. In online buying both types of uncertainty has to be reduced. A different study has described that in the buying process there are some degrees of interminable risk (Kim, 2000). In the Indian market the online buying is a new trend (Sahney, Ghosh \& Shrivastava, 2013; Mckinsey \& company, 2013). This online buying is increasing day-by-day with the growing use of internet \& smart phone users (BCG, 2015). The numbers of online retails are also growing and that is creating high competitive environment in online marketing.

\section{Tangible Economic benefits and intangible components and online shoppers' motivation}

Several researchers have illustrated that customer online purchase intention is significantly dominated by shopping orientations (Vijayasarathy \& Jones, 2000; Park, 2002; Gehrt, Onzo, Fujita \& Rajan, 2007). Shopping orientations is understood as a multi-dimensional construct. As per Gehrt, Onzo, Fujita \& Rajan, (2007), there is 7 major types of shopping orientations which consists of recreation, novelty, impulse purchase, quality, brand, price, and convenience. At online platform price related information along with the products description help the consumer in minimising investigation and purchasing costs (Kung, Monroe \& Cox, 2002; Phau \& Poon, 2000).
Price sensitivity works at online retail domain, price benefit also stimulates the potential buyer (Kung, Monroe \& Cox, 2002; Xinxin \& Lorin, 2010). In addition, price competition and offers/ promotions are having of significant role at online marketing and retailing area (Kung, Monroe \& Cox, 2002). Along with the price there are some other factors too, which may influence the consumer at online retail platform those are product variety surrounding security, promise fulfilment, confidence (Park, 2002; McCole, 2002; Gehrt Onzo, Fujita \& Rajan, 2007) Dependability (Swan, Trawick, Rink \& Roberts, 1988). Transactional safety (Tsiakis, 2012; Ray, Ow \& Kim, 2011) creates the trust feeling within the potential online buyer. Convenience is also equally important like aforesaid factors that motivates the online buyer to select the online transaction (Constantinides, 2004). Convenience includes saving time, site instructiveness, product navigation, updated information, site speed, simplicity in ordering and payment process, and accessibility (Constantinides, 2004; Wolfinbarger \& Gilly, 2001; Szymanski \& Hise, 2000). Along with the tangible benefits several intangible components also helps the online buyer in selection of an online brand. The tangible functionality \& intangible benefits jointly have the impact on consumer satisfaction in the realm of online marketing.

\section{Brand awareness and brand identity in online buying}

Brand awareness means the ability of a consumer can recognize and recall a brand in different situations (Aaker, 1996). Brand awareness consists of brand recall and brand recognition. Moreover, Hoeffler and Keller (2002) indicate that brand awareness can be distinguished from depth and width. Brand name is the most important element in brand awareness (Davis, Golicic \& Marquardt, 2008). A brand name offers a symbol that can assist consumers to identify service providers and to predict service results (Janiszewski \& Van Osselaer, 2000). Brand awareness plays an important role on purchase intention because consumers tend to buy a familiar and well known product (Keller, 1993; 
Macdonald \& Sharp, 2000). Brand awareness can help consumers to recognize a brand from a product category and make purchase decision (Percy \& Rossiter, 1992). Brand awareness has a great influence on selections and can be a prior consideration basein a product category (Hoyer \& Brown, 1990). Brand awareness also acts as a critical factor in the consumer purchase intention, and certain brands will accumulate in consumers' mind to influence consumer purchase decision. A product with a high level of brand awareness will receive higher consumer preferences because it has higher market share and quality evaluation (Grewal, Krishnan, Baker \& Borin, 1998). In this present era of online retailing this brand awareness plays a vital role, Cuthbertson and Bridson (2006) stated that online brand communities are having significant contributions in brand building at online platform. Numerous studies validated that consumer' purchase intentions and behaviours are directly influenced by online recommendations (Malhotra, Kubowicz \& See, 2013; Zhang et al.,2013; Hollebeek, Glynn \& Brodie, 2014) and digital WOM (e.g., Chang \& Chin, 2010; Lin, Tzeng, Ching \& Chang, 2009; Vimaladevi \& Dhanabkaym, 2012; Yali \& Bayram, 2012). According to David C. Edelman (2010) digital touch points are becoming very powerful in modern business environment which is complimented with offline promotion (Arce-Urriza \& Cebollada, 2012; Loureiro \& Roschk, 2014) to highlight the image of the online store. Brand Attachment and brand connection or association are very important elements in creation of enhanced consumer brand relationship (Keller, 1998; Park \& Stoel, 2010). Numerous studies have illustrated that human behaviour is significantly influenced by peers, in both network space and in time (e.g., Christakis \& Fowler, 2007; Crandall, Cosley, Huttenlocher, Kleinberg \& Suri, 2008; Aral, \& Van Alstyne, 2009). Blackwell et al. (2001) opinion leaders are the "individuals who lead in influencing others' options". According to Burt (1999) opinion leaders are the "people whose conversations make innovations contagious for the people with whom they speak". Social network has become a powerful platform (Duan et al. 2008, Kiss \& Bichler, 2008) which is acting as opinion leader in stimulating and motivating the thought process of the people in social network community.

Brand image is a powerful element in the contemporary competitive marketing environment which in turn influences consumer preferences (Keller 1993; Martínez \& De Chernatony, 2004). Aaker and Keller (1996), Aaker, Keller, and Joachimstaler (2000), and Keller (1993, 2003) have illustrated two main sources from where the consumer preferences relating to purchase intentions are generated for a particular brand viz: brand identity and brand image. Diverse marketing literature have discussed the concept of brand equity and its impacts on consumer (Farquhar, 1989 ; Keller, 2003), this thought is also becoming significantly important in online retailing domain (Yin-Chieh, Shu-Tzu \& Wei-Po, 2012) . Online store brand identity influence consumer's perception towards an online store's appeal. Several Studies have focused on the brand attributes that influences customer satisfaction and purchase intentions (Ou et al., 2010), therefore creation of brand equity is the key marketing objective for all the online retail stores (Yin-Chieh, Shu-Tzu \& Wei-Po, 2012) . Online retail brand has to connect itself with the consumer in better manner in generating the competitive advantage where the consumers will be happily expecting the online brands by triggering the different emotional components associated with online buying. Previous studies have demonstrated that brand equity of an online businesses are constructed upon five major elements namely emotional connection, online experience, customer service, trust, and fulfilment of Promises (Rios et al.2010).

\section{Trust matters in online buying}

Building trust with consumers (Festinger 1975; Hoffman, Novak \& Perlta, 1999) is an essential mission for e-retailers, because purchasing decisions represent trust-related behaviours (Jarvenpaa, Tractinsky \& Vitale, 2000; Urban, Sultan \& Qualls ,2000).Considerable research has focused on the critical role of trust, which plays a fundamental role in the success of 
online transactions and retailing (Chiu 2009; Gefen, Karahanna \& Straub, 2003; Wang, 2010; Kim, 2012; Svatošová, 2013). Trust and trustworthiness (Wang, 2010; Kim, 2012; Svatošová, 2013) plays a vital role in promoting a online retail brand. The trust factor in online marketing has been interpreted differently but some points are common those are online reviews (Liu, 2006). Similarly the distrust can be harmful for online retailing activity (Gefen 2003). Commitments and Consumer support are considered as very use full tools to enhance the trust level and positive feeling of the consumer (Srinivasan \& Moorman, 2005). Fulfilling the Promise (Jung et al., 2009; Grönroos 2009) is considered one of the most vital elements to create trust at online marketplace.

\section{Consumer experiences matters at online market place}

Online consumer experiences (OCEs) is connected with the psychological and emotional framework of any consumers when interacting with online products and brands ( $\mathrm{Li}, 2001)$. Earlier studies have recommended that OCEs may have positive persuasion effects (Keng \& Liu, 2013; Keng, Liao \&Yang, 2012; Keng, Ting \& Cheng, 2011; Li et al., 1999; Li, Daugherty \& Biocca, 2001; Li, Daugherty \& Biocca 2003). Poor customer experiences, such as delivery delay, may cause customer dissatisfaction if there are no appropriate arrangements of recovery strategy (Ahmad, 2002) have negative impact. Perceived comfort of usage and usefulness of online websites have exhibited significant influence on shopper intention to shop online (Honarbakhsh, Hooi, Kavianpour \& Shadkam, 2013), in this entire process online buyers experience and feel good factors contributes a lot. It is true that online retail websites performance and usefulness of online retail store can create an improved consumer attitude and purchase experience (Renny \& Siringoringo, 2013) which in, turn lead to repurchase.

\section{Social linkages in online buying}

Online buying is highly influenced by social networking communities \& internet social group that has been established by literature in online marketing arena (Liu, Tian, Wang \& Cui, 2011; Sridhar \& Srinivasan, 2012). The linking and support of online brand community has an intense impact on consumer buying decision making process (Lee, Lee, Taylor \& Lee, 2011; Brodie, Ilic, Juric \& Hollebeek, 2013; Brogi, 2014). The trust of the consumer at online platform is supported with online reviews \& experience sharing by the existing supports which acts as a brand advocacy too(Duan et al., 2008; Lee, Park \& Han, 2008; Lian \& Yen, 2013). Word of mouth communication is considered to be one of the powerful marketing mix to share information (Cheung, 2010), the effect of word of mouth communication is also becoming so powerful at digitised environment. That is also true for online buying platform. On one hand positive Digital word of mouth creates the better image of the online retail brands(Cheung, 2010; Feng \& Papatla, 2011; Cheung, 2014), on the other hand negative word of mouth demotivates the online buyers relating to a specific brand choice (Bambauer-Sachse \& Mangold, 2011; Verhagen, Nauta \& Felberg, 2013 ). The age of social networking has created a platform where the people of the same mentality, can come up together. The open discussion within the group and recommendations (Malhotra, Kubowicz \& See, 2013; Zhang et al.,2013; Hollebeek, Glynn \& Brodie, 2014) have a strong influence on online brand liking and selection . Group thinking \& peer pressure has a brilliant impact on consumption habit which is phenomenal relating to online buying among the youngsters (Hui \& Buchegger, 2009; Lim, Chan, Vedrevu \& Basnyat, 2013).

\section{Online retail brand engagement, brand connotation and Purchase intention}

Brand engagement is a process to create strong bonding in between the consumer and the brand by proper emotional and rational linkages (Goldsmith et al., 2012). At online market place engaging the consumers is very challenging task (Mollen \& Wilson, 2010; Wirtz Ambtman, Bloemer, Horváth, Ramaseshan, Klundert \& Canli, 2013). The different online marketers are using several ways in engaging the consumer 
by strategic use of social networking (Liu, Tian, Wang \& Cui, 2011; Sridhar \& Srinivasan, 2012), virtual brand community. This strategic use of social networking may help in achieving a better consumer-brand association (Verhagen \& Dolen, 2011; Romaniuk \& Nencyz, 2013) at online marketplace, which may also support in brand likeability (Brown, Zablah, Bellenger \& Donthu, 2012; Morgan-Thomas \& Veloutsou, 2013; Nepomuceno, Laroche \& Richard, 2014) of the online consumers. Online brand loyalty (Hur, Ahn \& Kim, 2011; Romaniuk \& Nencyz, 2013) and positive attitude (Yu \& Wang, 2011; Lee \& Kang, 2013; Romaniuk \& Nencyz, 2013) towards the brand is also highly connected with online retail brand engagement (Mollen \& Wilson, 2010; Brodie, Ilic, Juric \& Hollebeek, 2013; Wirtz, Ambtman, Bloemer, Horváth, Ramaseshan, Klundert \& Canli, 2013). Purchase intention is being discussed in various researches (Yoon, 2002; Gurviez \& Korchia, 2002), which is guided by many forces, but this actually leads to sales (Jiang, Chan, Tan \& Chua, 2010 ; Morwitz, Steckel \& Gupta, 2007; Choon \& Corresponding, 2010) . At on line platform purchase intention (Choon \& Corresponding, 2010; Hong \& Cha, 2013) is a most important because all the online brands want be picked up by the online buyers. Enhancing the dependable brand-customer relation (Wang, 2010; Kim,2012; Svatošová,2013) ,brand familiarity (Park \& Stoel, 2005; Benedicktus, Brady, Darke $\&$ Voorhees, 2010) and by consumer expectation $\&$ attitude management ( Kim,2012; Lee \& Kang, 2013; Romaniuk, \& Nencyz, 2013) .

From the literature review it can be argued that online marketing is becoming very interesting area of research because it is having a lot to do with the analysis of consumer psychology \& buying behaviour. Although it is a growing phenomenon in Indian market, even though less research has been undertaken in analysing the behaviour of the Indian consumer relating to online retail brand engagement, final brand selection and purchase intention in an integrated manner. The researches undertaken so far have been able to bring out the different components associated with online buying behaviour in an unintegrated manner. Few of the recent studies (Sahney, Ghosh \& Shrivastava, 2013) have tried to explore the various dimensions relating to buying behaviour of the Indian online shopper but they have restricted their study within the economic value and functional advantages.

\section{Objectives of the Study}

Although the aforesaid studies have tried to investigate the different aspect of online buying \& consumer behaviour, yet majority of the researchers have focussed on the different dimensions of the functional, behavioural, psychological and social aspects of online buying unconnectedly. There are less evidences of research which focuses on online retail brand engagement in a collective manner. This gap has inspired us to develop the objectives of the research:

- $\quad$ To identify the major factors that directly or indirectly effect online retail brand engagement,

- To examine the framework of online retail brand engagement in a collective manner for understanding the consumer buying behaviour in the Indian online marketplace, and

- $\quad$ To study the impact of online retail brand engagement on final brand selection and purchases in the Indian online marketplace.

In this research paper a framework to understand \& explore the linkages among Brand Trust (Liu, 2006; Wang,2010; Kim,2012; Svatošová,2013 ), Social Linkages(Liu, Tian, Wang \& Cui, 2011; Sridhar \& Srinivasan, 2012; Lian \& Yen, 2013; Malhotra, Kubowicz \& See, 2013; Hollebeek, Glyn \& Brodie, 2014), Brand Awareness (Keller, 1993; Aaker, 1996; Janiszewski \& Van Osselaer, 2000; Macdonald \& Sharp, 2000; Moreover et al.,2002; Davis, Golicic \& Marquardt, 2008) and snowballing of Online Retail Brand Engagement (Mollen \& Wilson, 2010; Brodie, Ilic, Juric \& Hollebeek, 2013; Wirtz, Ambtman, Bloemer, Horváth, Ramaseshan, Klundert \& Canli, 2013) in the Indian online buyer context is developed and tested. The hypothesized model also focussed on how the Online Retail Brand Engagement impacts the Final Brand 
Selection and Purchase Intention (Park \& Stoel, 2005; Benedicktus, Brady, Darke \& Voorhees, 2010; Choon \& Corresponding, 2010; Hong \& Cha, 2013 )

Research Hypotheses

H1 : Online Brand Trust of the potential buyers and the consumers' Social Linkages are interrelated.

H2 : Online Brand Trust of the potential consumers and online Brand Awareness are positively associated to each other.
H3 : Brand Trust will have a positive impact on Online Retail Brand Engagement.

H4 : Social Linkages will have a positive impact on Online Retail Brand Engagement.

H5 : Brand awareness will have a positive impact on Online Retail Brand Engagement.

H6 : Online Retail Brand Engagement will have a positive impact on Final Brand Selection and Purchase Intention.

\section{Proposed hypothetical model}

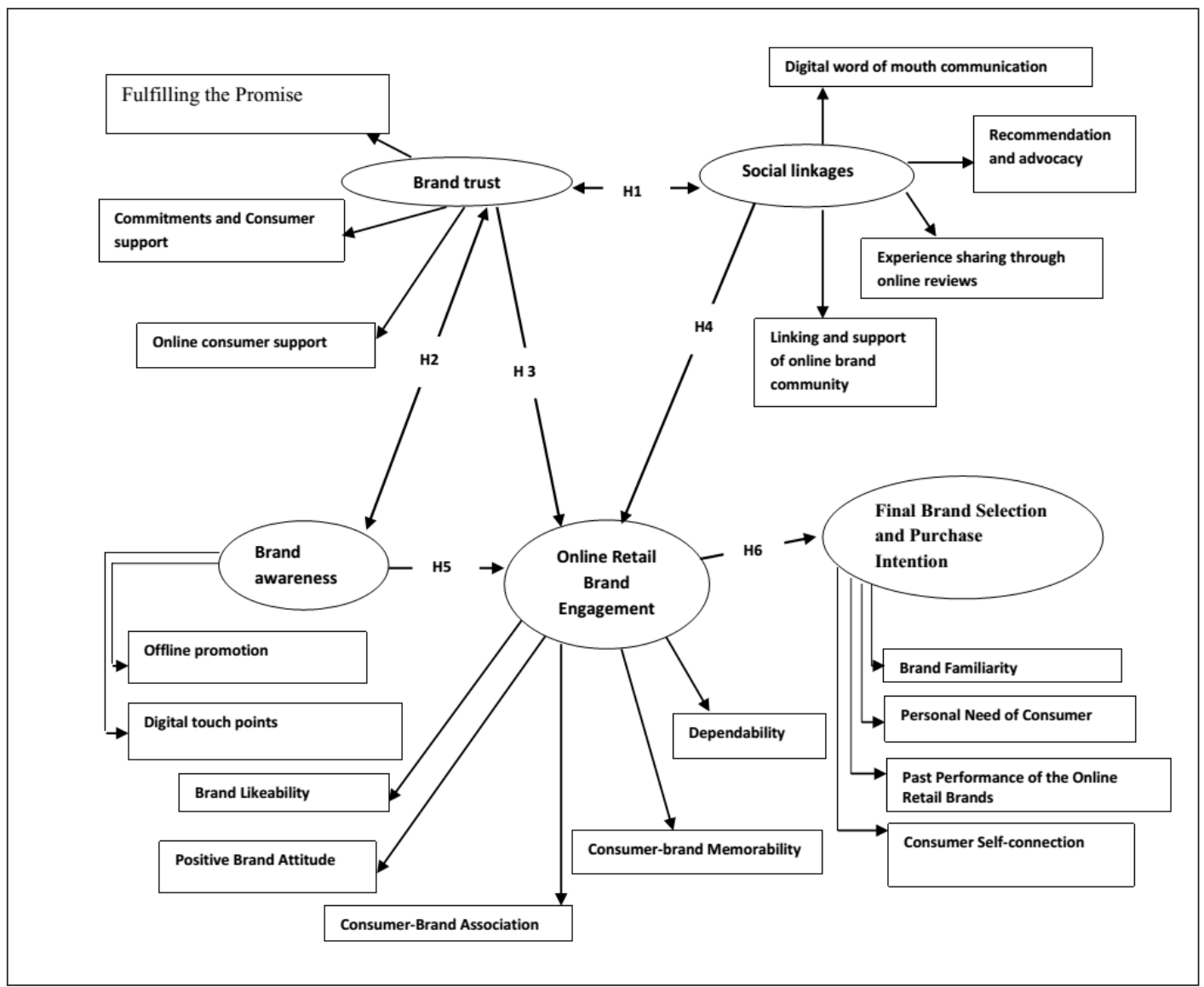

Figure1. Hypotheses-based Model

\section{Methodology}

The research is based on an exhaustive literature review of the components directly and indirectly related to the proposed hypothetical model. The population is composed of all Indian buyers of age more than 22 years and who shop from online stores. Sample responses were collected from 
the internet survey using a list-based sampling frame (Couper, 2000; Dominelli, 2003), which is very common and popular method in online retailing research (Couper, 2000). The sample frame consists of residents from the 3 metropolitan cities of India- Bangalore, Kolkata \& Delhi. In this study we have gathered the basic consumer contacts related data from two major (name is not disclosed for confidentiality purposes) online retailers in India, which has helped us to create a sizeable database of 2,685 Indian online buyers. Then 600 potential online buyers were randomly selected from our harvested online buyers' database by using the 'RANDBETWEEN' function in Microsoft Excel-2010. Sample responses were constructed using effective Web survey design (Couper et al., 2001; Dillman \& Bowker, 2001; Dillman, 2000) by using a list-based sampling frame (Couper, 2000; Dominelli, 2003). A structured online questionnaire (as prescribed by Dillman, 2000; Torangeau et al., 2003) has been used as the tool for data collection. The entire data were collected between February $10^{\text {th }}$ to May $23^{\text {rd }}$, 2015. The responses were recorded using fivepoint Likert (1- fully disagree, 5 -fully agree). Total of 277(out of 600 email communication) responses were received in online survey but due to the data insufficiency only 252 responses are used in the current research. The other items consisted of demographic profiles (mean age $=27.4$ years, female $=35.8$ percent, graduate $=53.5$ percent, post-graduate $=27.3$ percent, mean monthly household income = INR 63,000). Next, for extracting the vital underlying dimensions in a more controllable manner, a series of exploratory factor analyses with principal components analysis (varimax rotation) was executed (Netemeyer et al., 2003; Briggs and Cheek, 1986). During the factor analysis the items that loaded on more than one factor along with low factor loadings $(<$ 0.60) were eliminated (Kline, 1998; Anderson and Gerbing, 1988). After the exploratory factor analyses, we conducted confirmatory factor analysis (Hair, Black, Babin, Anderson $\&$ Tatham, 2008) using AMOS (version 20) to recheck the output of exploratory factor analysis along with the testing of hypotheses-based model. Before proceeding with the analysis of structural equation modeling, multivariate normality test were carried out (Hair, Black, Babin, Anderson \& Tatham, 2008) to identify the robustness of the analysis. The results of confirmatory factor analysis demonstrated that the data fit the proposed model of thet research (covariance within constructs: e.g. Hair Black, Babin, Anderson \& Tatham, 2008). All factor loadings were higher than 0.50 (Hair, Black, Babin, Anderson \& Tatham, 2008) and are significant at the 0.001 level indicating convergent validity (Kline, 1998; Anderson and Gerbing, 1988).

\section{Data Analysis and Findings}

\section{Construct validity}

In this research we have considered 18 independent variables, those individual components have been instrumental in construction of the constructs. All the constructs or the dimensions have a minimum of three items and maintained the minimum requirement for structural equation modelling (Hair, Black, Babin, Anderson \& Tatham, 2008). The sample size of present study falls within the suggested number of $150-400$, which is basic minimum criteria for conducting Structural equation modelling (Hair, Black, Babin, Anderson \& Tatham, 2008). The proposed structural equation modelling was tested (with AMOS, version - 20) using covariance matrix of the relevant indicators as input with maximum likelihood estimation method. Out of 18 items, 13 variables indicated factor loadings greater than 0.70 and others are greater than 0.60 . As a good rule of thumb, factor loadings of 0.50 or higher, and ideally 0.70 or higher are acceptable (Hair, Black, Babin, Anderson \& Tatham, 2008). All loadings are significant (p-value $<0.00$ ) and thus confirmed convergent validity of constructs (Kline, 1998; Anderson and Gerbing, 1988). 
From Table-1 it is evident that all Composite Reliability (CR) values meet the minimum standard (with values 0.70 and above, Hair, Black, Babin, Anderson \& Tatham, 2008) which approve the internal consistency of the model constructs. The CR of all factors or dimensions are: Brand Trust (0.755), Social Linkages (0.832), Brand Awareness (0.725), Online Retail Brand Engagement (0.857), and Final Brand Selection and Purchase Intention respectively (0.838). The Average Variance Extracted (AVE) of all construct are: Brand Trust (0.507), Social Linkages (0.554), Brand Awareness (0.569), Online Retail Brand Engagement (0.547) and Final Brand Selection and Purchase Intention respectively (0.567). All different dimensions maintained the minimum criteria of convergent $(\mathrm{AVE}=0.50$, Hair et al., 2008).

\section{Normality and Reliability analysis}

Multivariate normality was assessed using AMOS (version 20). Multivariate normality was also assessed using Mardia's coefficient (Mardia, 1970), as a rule of thumb, should be within the range of even +/- 2.0 (Schumacker and Lomax, 2004). However, Mardia's coefficient suggested that the data did not follow multivariate normality (Mardia's coefficient $=52.263$; critical ratio $=18.6$ ). To overcome this specific problem in structural equation modelling in the current study arising from failure to achieve multivariate normality maximum likelihood estimation is used to achieve robust nonnormality situations. From Table- 1 it is evident all item loadings were having values greater than 0.60 (Nunnally, 1978, Hair et al., 2008) and are significant at the 0.001 level indicating convergent validity (Kline, 1998; Anderson et al., 1988). From Table- 1 it is also evident that all the Cronbach's $\alpha$ coefficients of the scale dimensions are $0.681,0.739,0.662,0.628$ and 0.717 for Brand Trust, Social Linkages, Brand Awareness, Online Retail Brand Engagement, and Final Brand Selection and Purchase Intention respectively. The Cronbach's $\alpha$ coefficients met the minimum level of 0.70 (Hair, Black, Babin, Anderson \& Tatham, 2008) which thus confirmed the reliability of the model dimensions.

\section{Goodness-of-Fit Indexes for Measurement Model}

The model fit indices also provide a reasonable model fit for the structural model. Chi-square statistic is 546.948 (Probability level=.000), प 2 / d. f. is 2,989, The Normed fit Index (NFI), Relative Fit index (RFI), Comparative Fit index (CFI), Tucker Lewis Index (TLI), Goodness of Fit Index(GFI) and Adjusted Goodness of Fit Index (AGFI) are 0.895, $0.877,0.968,0.954,0.886,0.875$ respectively. RMSEA is 0.0614, PCLOSE is 0.00 and the Standardized RMR is 0.0271 . Hence it can be concluded that the research model fit reasonably well (Kline, 2005; Hair, Black, Babin, Anderson \& Tatham, 2008; Byrne, 2010; Hu \& Bentler, 1999).

\section{Outcome of Structural equation modeling and path analysis}

In testing of the impact using t-test and p-values, significant positive impacts with regard to the proposed model (Table-2 and Table-3) were obtained. Statistical outcomes have demonstrated that Brand Trust and Social Linkages have significant positive connection (Path Coefficient $=0.462, \mathrm{t}=3.228$, $\mathrm{p}$-value $<$ 0.01), Brand Trust and the Brand Awareness have significant positive association (Path Coefficient $=0.627, \mathrm{t}=4.502$, $\mathrm{p}$-value $<0.01$ ) The results demonstrated that Brand Trust has a a positive impact on Online Retail Brand Engagement $($ Path Coefficient $=0.463, \mathrm{t}=3.837$, p-value $<0.01)$, Social Linkage has a positive influence on Online Retail Brand Engagement (Path Coefficient $=0.681, \mathrm{t}=6.827, \mathrm{p}$-value $<0.01$ ), Brand Awareness has a positive effect on Online Retail Brand Engagement (Path Coefficient $=0.41, \mathrm{t}=3.868, \mathrm{p}$-value $<$ $0.05)$. Finally the outcome of the $t$ research has established that the Online Retail Brand Engagement has a strong positive influence on Final Brand Selection and Purchase Intention (Path Coefficient $=0.962, \mathrm{t}=7.55, \mathrm{p}$-value $<$ 0.05). 


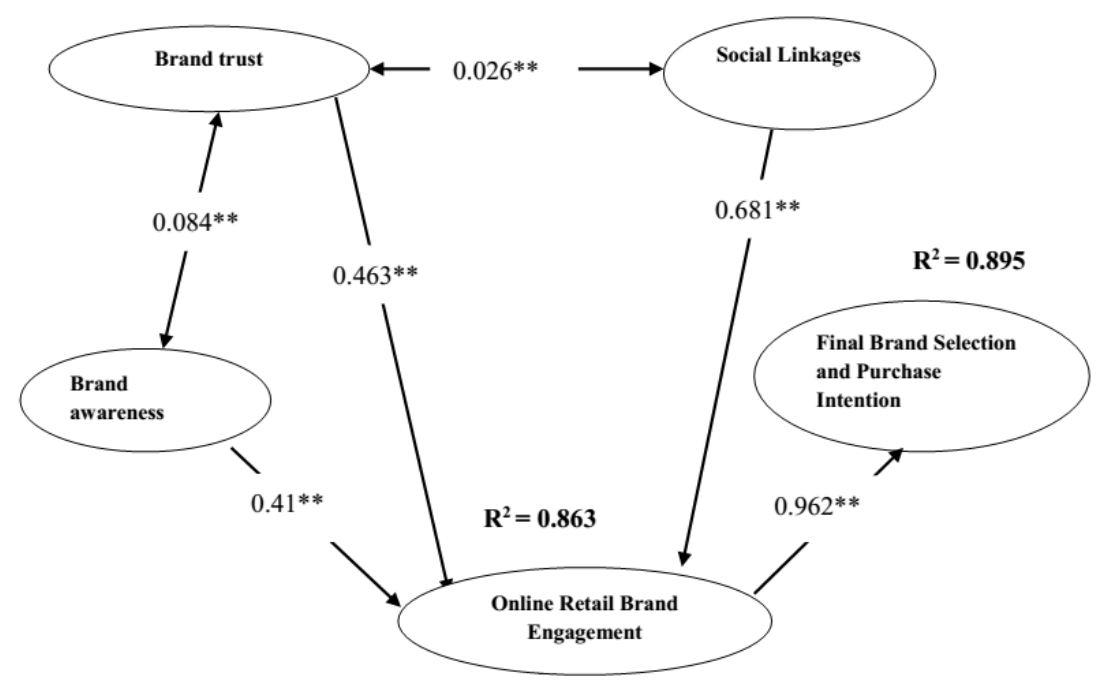

(1) Figure 2. Standardized Model with Path Coefficients (*: $\mathrm{p}<0.01 ; * *$ : $<<0.05)$

\section{Analysis of Measurement Model}

Table 1

Measurement Construct Wise Model Fit Indices

\begin{tabular}{|c|c|c|c|c|}
\hline Factors/items & $\begin{array}{c}\text { Standardized } \\
\text { factor loading }\end{array}$ & AVE & $\mathrm{CR}$ & $\begin{array}{c}\text { Cronbach's } \\
\text { Alpha }\end{array}$ \\
\hline \multicolumn{5}{|l|}{ Brand Trust } \\
\hline Fulfilling the Promise & 0.749 & \multirow{3}{*}{0.507} & \multirow{3}{*}{0.755} & \multirow{3}{*}{0.681} \\
\hline Commitments and Consumer support & 0.680 & & & \\
\hline Online consumer support & 0.706 & & & \\
\hline \multicolumn{5}{|l|}{ Social Linkages } \\
\hline Experience sharing through online reviews & 0.738 & & & \\
\hline Digital word of mouth communication & 0.813 & \multirow{3}{*}{0.554} & \multirow{3}{*}{0.832} & \multirow{3}{*}{0.739} \\
\hline Linking and support of online brand community & 0.726 & & & \\
\hline Recommendation and advocacy & 0.694 & & & \\
\hline \multicolumn{5}{|l|}{ Brand awareness } \\
\hline Offline promotion & 0.783 & \multirow[t]{2}{*}{0.569} & \multirow[t]{2}{*}{0.725} & \multirow[t]{2}{*}{0.662} \\
\hline Digital touch points & 0.725 & & & \\
\hline \multicolumn{5}{|l|}{ Online Retail Brand Engagement } \\
\hline Dependability & 0.722 & \multirow{5}{*}{0.547} & \multirow{5}{*}{0.857} & \multirow{5}{*}{0.628} \\
\hline Brand likeability & 0.686 & & & \\
\hline Consumer-brand association & 0.694 & & & \\
\hline Positive Brand attitude & 0.816 & & & \\
\hline Consumer-Brand Memorability & 0.771 & & & \\
\hline
\end{tabular}




\begin{tabular}{|c|c|c|c|c|}
\hline Factors/items & $\begin{array}{l}\text { Standardized } \\
\text { factor loading }\end{array}$ & AVE & $\mathrm{CR}$ & $\begin{array}{c}\text { Cronbach's } \\
\text { Alpha }\end{array}$ \\
\hline Final Brand Selection and Purchase Intention & & 0.567 & 0.838 & 0.717 \\
\hline Past performance of the online retail brands & 0.735 & & & \\
\hline Personal need of consumer & 0.623 & & & \\
\hline Brand familiarity & 0.772 & & & \\
\hline Consumer self-connection & 0.863 & & & \\
\hline
\end{tabular}

Table 2a

Testing of Hypotheses (Measurement of Covariance)

\begin{tabular}{lrrrr}
\hline \multicolumn{2}{c}{ Covariance } & & & \\
\hline Hypothesis & Estimate & S.E. & C.R. & Result \\
H1: Social Linkages $<->$ Brand Trust & $0.026^{* *}$ & 0.008 & 3.228 & Acceptable \\
H2: Brand Awareness $<->$ Brand Trust & $0.084 * *$ & 0.031 & 4.502. & Acceptable \\
\hline
\end{tabular}

$(*: \mathrm{p}<0.05 ; * *: \mathrm{p}<0.01)$

Table $2 b$

Testing of Hypotheses (Measurement of Correlations)

\begin{tabular}{lc}
\hline Hypothesis & Correlation \\
\hline H1: Social Linkages <--> Brand Trust & $0.638^{* *}$ \\
H2: Brand Awareness <--> Brand Trust & $0.715^{* *}$ \\
\hline
\end{tabular}

$(*: \mathrm{p}<0.05 ; * *: \mathrm{p}<0.01)$

Table 3

Testing of Hypotheses

\begin{tabular}{lcccc}
\hline & $\begin{array}{c}\text { standardized } \\
\text { Path } \\
\text { Hypothesis }\end{array}$ & & & \\
coefficients & S.E. & C.R. & Result \\
\hline H3: Online Retail Brand Engagement <--- Brand Trust & $0.463^{* *}$ & 0.661 & 3.837 & Acceptable \\
H4: Online Retail Brand Engagement <--- Social Linkages & $0.681^{* *}$ & 0.935 & 6.827 & Acceptable \\
H5: Online Retail Brand Engagement <--- Brand Awareness & $0.41^{* *}$ & 0.265 & 3.868 & Acceptable \\
$\begin{array}{l}\text { H6: Final Brand Selection and Purchase Intention <--- Online Retail } \\
\text { Brand Engagement }\end{array}$ & $0.962^{* *}$ & 0.734 & 7.551 & Acceptable \\
\hline
\end{tabular}

$(*: \mathrm{p}<0.05 ; * *: \mathrm{p}<0.01)$

\section{Discussion and Implication}

The first objective of the study was to identify the component which have connections with Online Retail Brand Engagement (Mollen \& Wilson, 2010; Brodie, Ilic, Juric \& Hollebeek,
2013; Wirtz, Ambtman, Bloemer, Horváth, Ramaseshan, Klundert \& Canli, 2013).The present study has demonstrated that the linkages among the Brand Trust (Liu, 2006; Wang,2010; Kim,2012; Svatošová,2013), Social Linkages(Eri et al.,2011; Liu, Tian, Wang \& 
Cui, 2011; Sridhar \& Srinivasan, 2012; Lian \& Yen, 2013; Malhotra, Kubowicz \& See, 2013; Hollebeek, Glynn \& Brodie, 2014), and Brand Awareness (Keller, 1993; Aaker, 1996; Janiszewski \& Van Osselaer, 2000; Macdonald \& Sharp, 2000; Moreover et al.,2002; Davis, Golicic \& Marquardt et al., 2008) are significant in an Indian online consumer buying behaviour context .On the one side outcomes of the present research have established that Brand Awareness and Social Linkage are highly correlated with Brand Trust. On the other side, outcomes of the present research has shown that Brand Awareness, Social Linkage and Brand Trust has significant positive impact on Online Retail Brand Engagement.

The second objective of the study was to analyse the process of how to build up the Online Retail Brand Engagement in an integrated manner in online market place. The results of the present research have exhibited that contributions of Brand Trust, Social Linkages and Brand Awareness are required in the entire process to create Online Retail Brand Engagement. In this process Brand Trust is constructed by fulfilling the promise (Jung et al., 2009; Grönroos 2009), commitments and consumer support (Srinivasan \& Moorman, 2005). Social Linkages is significantly associated with the digital word of mouth communication(Cheung ,2010; Feng \& Papatla, 2011; Cheung,2014), linking \& support of the online brand communities(Lee, Lee, Taylor \& Lee, 2011; Brodie, Ilic, Juric \& Hollebeek, 2013; Brogi, 2014), online reviews \& experience sharing (Duan et al.,2008; Lee, Park \& Han, 2008; Lian \& Yen, 2013) and recommendations (Malhotra \& Kubowicz, 2013; Zhang et al.,2013; Hollebeek, Glynn \& Brodie, 2014). Brand Awareness is significantly connected with the Offline promotion (ArceUrriza \& Cebollada, 2012; Loureiro et al., 2014) and Digital touch points (David, 2010).

The third objective of the study was to analyse how Online Retail Brand Engagement affect the Final Brand Selection and Purchase Intention (Park \& Stoel, 2005; Benedicktus et al., 2010;
Choon \& Corresponding, 2010; Hong \& Cha, 2013). The results have confirmed that Final Brand Selection and Purchase Intention is highly influenced by Online Retail Brand Engagement. The outcomes have clearly demonstrated that in the entire process to create Online Retail Brand Engagement any online retail brand must be proven to be dependable (Swan, Trawick, Rink \& Roberts, 1988; Wang, 2010; Kim, 2012; Svatošová,2013), likeable (Brown et al.,2012; Morgan-Thomas \& Veloutsou, 2013; Nepomuceno, Laroche \& Richard, 2014), enhance consumer-brand association(Verhagen \& Van Dolen, 2011; Romaniuk \& Nenycz-Thiel, 2013) and develop positive brand attitude of the online buyer (Yu et al., 2011; Lee \& Kang, 2013; Romaniuk \& Nenycz-Thiel, 2013).

This research article has revealed that consumer trust depends on the overall service quality of the online retail brands and is positively associated with social linkages and brand awareness. Our model has confirmed that to achieve brand engagement at online marketplace is an integrated process where the online retail brands have to be very cautious because Indian online buyers are not only quality sensitive but also emotionally coupled with the society. So besides providing the good online shopping experiences to the customers, the online retail brand mast put their effort in generating organic WOM to connect the buyer society at large. This will actually help the online retail brands in buildup higher online retail brand engagement in terms of consumer brand- likeability, enhanced brand memorability and positive brand attitude with higher consumer-brand association. The improved online retail brand engagement will definitely have the positive impact on the final online retail brand selection and purchase.

\section{Conclusions and Managerial Implications}

This study has several managerial implications. In recent times, researchers have tried to explore the different dimensions of online marketing relating to Indian context (Mahapatra 
\& Sreekumar, 2012; Nayyar \& Gupta, 2011; Sahney, Ghosh \& Shrivastava, 2013; Thamizhvanan \& Xavier, 2013) but they have restricted their study within the economic value and functional advantages. There have been no such empirical evidences that can portray process in knowing how the Online Retail Brand Engagement can be strategically created to support the Final Brand Selection and Purchase Intention of the potential customer at Indian online marketplace. Our present study can be seen as the first empirical evidence in this regard. This study has demonstrated that in online marketplace, Brand Trust, Social Linkages and Brand Awareness are positively related to each other and jointly influence the Online Retail Brand Engagement, this actually leads to Final Brand Selection and Purchase Intention (Park \& Stoel, 2005; Benedicktus, Brady, Darke \&Voorhees, 2010; Choon \& Corresponding, 2010; Hong \& Cha, 2013). The proposed model in this present research article may function as the road-map for the new age online multinational brands to take a deeper look into what can be done to create higher consumer brand engagement in the Indian online marketplace by triggering the social linkages, emotional linkages and economic values. This would lead to a gain in competitive advantage which will motivate the online buyer.

\section{Limitations and Future Scope}

The study focused on Indian consumers who buy online. This research covered only 3 metropolitan cities of India, namely Bangalore, Calcutta and Delhi. Further investigation is required before any generalisation of these results can be undertaken. So future studies can replicate the present study in various dimension of online marketing by integrating the components namely; Brand Trust, Social Linkages, Brand Awareness, Online Retail Brand Engagement and Final Brand Selection \& Purchase Intention. The overall model in this current research stands right but with the different sample size, statistical outcomes might change. We also recommend replicating the study in other countries

\section{References}

Aaker, D.A. (1996). Measuring Brand Equity across products and markets. California Management Review, 38(3), 102-20.

Aaker, David, A., \& Erich Joachimsthaler. (2000). Brand Leadership, London, Free Press.

Ahmad, S. (2002). Service failures and customer defection: A closer look at onlineshopping experiences. Managing Service Quality, 12(1), 19-29.

Anderson, J.C., \& Gerbing, D.W. (1988). Structural modeling in practice: A review and recommended two-step approach. Psychological Bulletin, 103(3), 411-23

Aral, S., M. Van Alstyne. (2009). Networks, information and brokerage-the diversity-Brandwidth trade off. Working paper, Leonard N. Stern School of Business, New York University, New York.

Arce-Urriza, M., \& Cebollada, J. (2012). Private labels and national brands across online and offline channels. Management Decision, 50(10), 1772-1789.

Bambauer-Sachse, S., \& Mangold, S. (2011). Brand equity dilution through negative online word-of-mouth communication. Journal of Retailing and Consumer Services, 18(1), 38-45.

Benedicktus, R. L., Brady, M. K., Darke, P. R., \& Voorhees, C. M. (2010). Conveying Trustworthiness to Online Consumers: Reactions to Consensus, Physical Store Presence, Brand Familiarity, and Generalized Suspicion. Journal of Retailing, 86(4), 310-323.

Bhatnagar, A., \& Ghose, S. (2004). Online information search termination patterns across product categories and consumer demographics. Journal of Retail, 80:221 -8 .

Blackwell, R. D., Miniard, P. W., \& Engel, J. F. (2001). Consumer behavior. (9th ed). Orlando: Harcourt College Publishers.

Brodie, R. J., Ilic, A., Juric, B., \& Hollebeek, L. (2013). Consumer engagement in a 
virtual brand community: An exploratory analysis. Journal of Business Research, 66(1), 105-114.

Brogi, S. (2014). Online Brand Communities: A Literature Review. Procedia - Social and Behavioral Sciences, 109, 385-389.

Brown, B. P., Zablah, A. R., Bellenger, D. N., \& Donthu, N. (2012). What factors influence buying center brand sensitivity? Industrial Marketing Management, 41(3), 508-520.

Burt, R.S. (1999). The social capital of opinion leaders. Annals of the American Academy of Political and Social Science, November: 1-22.

Byrne, B. M. (2010). Structural equation modeling with AMOS (2nd ed.). New York: Routledge.

Chang, C.C., \& Chin, Y.C. (2010). The impact of recommendation sources on online purchase intentions: the moderating effects of gender and perceived risk. World Academy of Science, Engineering and Technology, 66(June), 111-114.

Cheung, C. M. K. (2010). The Effectiveness of ElectronicWord-of-MouthCommunication: A Literature Analysis Electronic Word-ofMouth Communication. Communication, 329-345.

Cheung, R. (2014). The influence of electronic word-of-mouth on information adoption in online customer communities. Global Economic Review, 43(1), 42-57.

Chiu, C. M., Chang C.C., Cheng, H. L., \& Fang, Y. H. (2009). Determinants of customer repurchase intention in online shopping[ Online Information Review, 33(4), 761 $-784$

Choon, K., \& Corresponding, L. (2010). The Effects of Shopping Orientations , Online Trust and Prior Online Purchase Experience toward Customers ' Online Purchase Intention. International Business Research, 3, 63-76. Retrieved from

Christakis, N. A., \& J. H. Fowler. (2007). The spread of obesity in a large social network over 32 years. New England J. Med, 357 (4), 370-379.
Comegys, C., Hannula, M., \& Väisänen, J. (2009). Effects of consumer trust and risk on online purchase decision-making: A comparison of Finnish and United State Students. International Journal of Management, 26(2), 295-308.

Constantinides, E. (2004). Influencing the online consumers behaviour: The Web experience. Internet Research. 14(2), 111-126.

Couper, Mick, P. (2000) Review: Web Surveys: A Review of Issuesand Approaches. The Public Opinion Quarterly, 64(4), 464494.

Crandall, D., D. Cosley., D. Huttenlocher., J. Kleinberg., \& S. Suri. (2008). Feedback effects between similarity and social influence in online communities. Proc. 14th ACM SIGKDD Internat. Conf. Knowledge Discovery Data, Las Vegas, NV, ACM, New York, 160-168.

Cuthbertson, R.W. \& Bridson, K. (2006), Online retail loyalty strategies. International Journal of Information Technology and Management, 5(4), 279-94.

Davis, D. F., Golicic, S. L., \& Marquardt, A. J. (2008). Branding a B2B service: Does a brand differentiate a logistics service provider? Industrial Marketing Management, 37, 218-227.

Dillman, D.A., \& Bowker, D.K. (2001). The Web questionnaire challenge to survey methodologists. In $U$. Reips \& $\mathrm{M}$. Bosnjak (Eds.), Dimensions of Internet Science. Lengerich, Germany: Pabst Science Publishers.

Dillman, D.A. (2000). Mail and Internet surveys: The tailored design method (2nd ed.). Wiley: NY

Dominelli, A. (2003). Web surveys - benefits and considerations. Clinical Research and Regulatory Affairs. 20(4), 409-416.

Edelman, D. C. (2010). Branding in the digital age: Youlre spending your money in all the wrong places. Harvard Business Review, 88(12).

Farquhar, P. (1989). Managing Brand Equity. Journal of Advertising Research, 30, 4, RC7-RC12. 
Feng, J., \& Papatla, P. (2011). Advertising: Stimulant or Suppressant of Online Word of Mouth? Journal of Interactive Marketing, 25(2), 75-84.

Festinger, L. (1957). A theory of cognitive dissonance. Stanford, CA: Stanford University Press.

Forsythe, S., \& Shi, B. (2003). Consumer patronage and risk perceptions in Internet shopping. Journal of Business Research, 56, 867-875.

Gefen, D., Karahanna, E., \& Straub, D. (2003). Trust and TAM in online shopping: An integrated model. MIS quarterly, 27(1), 51-90.

Gehrt, K.C., Onzo, N., Fujita, K., \& Rajan, N.R (2007). The emergence of internet shopping in Japan: Identification of shopping orientation-defined segment. Journal of Marketing Theory and Practice, 15(2), 167-177.

Grewal, D., Krishnan, R., Baker, J., \& Borin, N. (1998). The effect of store name, brand name, and price discounts on consumer's evaluations and purchase intentions. Journal of Retailing, 74(3), 331-352.

Grönroos, C. (2009). Marketing as promise management: regaining customer management for marketing. Journal of Business and Industrial Marketing, 24(5/6),351-359.

Gurviez, P., \& Korchia, M. (2002). Proposition d'une échelle de mesure multidimensionnelle de la confiance dans La Marque. Recherche et Application en Marketing, 17(3), 41-61.

Hair, J.F., Black, W.C., Babin, B.J., Anderson, R.E., \& Tatham, R.L. (2008). Multivariate Data Analysis (6th ed.). Pearson Education, New Delhi.

Hoffman, D.L., Novak, T.P., \& Perlta, M. (1999). Building consumer trust onlinel. Association for Computing Machinery Communications of the ACM, 42(4), 8085.

Hollebeek, L. D., Glynn, M. S., \& Brodie, R. J. (2014). Consumer Brand Engagement in Social Media: Conceptualization, Scale
Development and Validation. Journal of Interactive Marketing, 28(2), 149-165.

Honarbakhsh, S., Hooi, L.W., Kavianpour, S., \& Shadkam, M. (2013). Antecedents of consumers intention to shop online. Australian Journal of Basic and Applied Sciences, 7(13), 190-197.

Hong, I. B., \& Cha, H. S. (2013). The mediating role of consumer trust in an online merchant in predicting purchase intention. International Journal of Information Management, 33(6), 927-939.

Hoyer, W. D., \& Brown, S. P. (1990). Effects of brand awareness on choice for a common repeat-purchase product. Journal of Consumer Research, 17(2), 141-148.

Hu, L., \& Bentler, P. M. (1999). Cutoff criteria for fit indexes in covariance structure analysis: Conventional criteria versus new alternatives. Structural Equation Modeling, 6, 1-55.

Hui, P., \& Buchegger, S. (2009). Groupthink and Peer Pressure: Social Influence in Online Social Network Groups. 2009 International Conference on Advances in Social Network Analysis and Mining ( 53-59). IEEE.

Hur, W.-M., Ahn, K.-H., \& Kim, M. (2011). Building brand loyalty through managing brand community commitment. Management Decision, 49(7), 1194-1213

Janiszewski, C., \& Van Osselaer, M. J. (2000). A connectionist model of brand-quality associations. Journal of Marketing Research, 37(3), 331-350.

Jarvenpaa, S. L., Tractinsky, N., \& Vitale, M. (2000). Consumer trust in an Internet store. Information Technology and Management, 1(12), 45-71.

Jiang, Z., Chan, J., Tan, B., \& Chua, W. S. (2010). Effects of interactivity on website involvement and purchase intention. Journal of the Association for Information Systems, 11(1), 34-59.

Keller, K. L. (1993). Conceptualizing, measuring, and managing customerbased brand equity. Journal of Marketing, 57(1), 1-22. 
Keller, K.L. (2001). Building customer-based brand equity. Marketing Management, 10 (2), . 14-21.

Keng, C. J., \& Liu, C. C. (2013). Can avatar and self-referencing really increase the effects of online 2-D and 3-D advertising? Computers in Human Behavior, 29(3),791-802.

Keng, C. J., Liao, T. H., \& Yang, Y. I. (2012). The effects of sequential combinations of virtual experience, direct experience, and indirect experience: The moderating roles of need for touch and product involvement. Electronic Commerce Research, 12(2), 177-199.

Keng, C. J., Ting, H. Y., \& Chen, Y. T. (2011). Effects of virtual-experience combinations on consumer-related sense of virtual community. Internet Research, 21(4), 408-434.

Kim, C., Galliers, R. D., Shin, N., Ryoo, J. H., \& Kim, J. (2012). Factors influencing Internet shopping value and customer repurchase intention. Electronic Commerce Research and Applications, 11(4), 374-387.

Kim, D. J. (2012). An investigation of the effect of online consumer trust on expectation, satisfaction, and post-expectation. Information Systems and e-Business Management, 10(2), 219-240.

Kim, H.S. (2000). Discriminative factors of buying intension in fashion Internet shopping, Unpublished doctoral dissertation. Sookmyung Womans University.

Kiss, C., \& Bichler, M. (2008). Identification of influencers - measuring influence in customer networks. Decision Support Systems, 46(1), 233-253.

Kline, R.B. (2005), Principles and Practice of Structural Equation Modeling (2nd Ed.). New York: The Guilford Press.

Kung, M., Monroe, B. K., \& Cox, J. (2002). Pricing on the Internet. Journal of Products and Brand Management, 11(2), $274-287$.

Lee, H. J., \& Kang, M. S. (2013). The effect of brand personality on brand relationship, attitude and purchase intention with a focus on brand community. Academy of Marketing Studies Journal, 17(2), 8598.

Lee, H. J., Lee, D.-H., Taylor, C. R., \& Lee, J.H. (2011). Do online brand communities help build and maintain relationships with consumers? A network theory approach. Journal of Brand Management. 19(3), 213-227.

Lee, H., Kim, J., \& Fiore, A. (2010). Affective and Cognitive Online Shopping Experience: Effects of Image Interactivity Technology and Experimenting With Appearance. Clothing and Textiles Research Journal, 28(2), 140.

Lee, J., Park, D. H., \& Han, I. (2008). The effect of negative online consumer reviews on product attitude: An information processing view. Electronic Commerce Research and Applications, 7(3), 341352.

Li, H., Daugherty, T., \& Biocca, F. (2001). Characteristics of virtual experience in electronic commerce: A protocol analysis. Journal of Interactive Marketing, 15(3), 13-30.

Li, H., Daugherty, T., \& Biocca, F(2003). The role of virtual experience in consumer learning. Journal of Consumer Psychology, 13(4), 395-407.

Lian, J. W., \& Yen, D. C. (2013). To buy or not to buy experience goods online: Perspective of innovation adoption barriers. Computers in Human Behavior, 29(3), 665-672.

Lim, S. S., Chan, Y. H., Vadrevu, S., \& Basnyat, I. (2013). Managing peer relationships online-Investigating the use of Facebook by juvenile delinquents and youths-at-risk. Computers in Human Behavior, 29(1), 8-15.

Lin, C.S., Tzeng, G.H., Chin, Y.C., \& Chang, C.C. (2009). The effect of recommendation sources and consumer involvement on trust and purchase intentions in online and offline environments. 
Liu, X., Tian, Y., Wang, W., \& Cui, Y. (2011). A social network-based trust model for group-buying. Proceedings - 2011 4th IEEE International Conference on BroadBrand Network and Multimedia Technology, IC-BNMT , 385-389.

Liu, Y. (2006). Word of mouth for movies: Its dynamics and impact on box office revenue. Journal of Marketing, 70 ((July) 74-89.

Loureiro, S. M. C., \& Roschk, H. (2014). Differential effects of atmospheric cues on emotions and loyalty intention with respect to age under online/offline environment. Journal of Retailing and Consumer Services, 21(2), 211-219.

Macdonald, E. K., \& Sharp, B. M. (2000). Brand awareness effects on consumer decision making for a common, repeat purchase product: A replication. Journal of Business Research, 48, 5-15.

Mahapatra, S. \& Sreekumar. (2012). A RIDIT approach to evaluate factors influencing online shopping behaviour, International. Journal of Internet Marketing and Advertising, 7(1), 83-99.

Malhotra, A., Kubowicz Malhotra, C., \& See, A. (2013). How to Create Brand Engagement on Facebook. MIT Sloan Management Review, 54(2), 18-20.

Martínez, E., \& De Chernatony, L. (2004). The effect of brand extension strategies upon brand image. Journal of Consumer Marketing, 21(1), 39-50.

McCole, P. (2002). The role of trust for electronic commerce in services. International Journal of Contemporary Hospitality Management, 14(2), 81-87.

McCole, P., Ramsey, E., \& Williams, J. (2009). Trust considerations on attitudes towards online purchasing: the moderating effect ofprivacy and security concerns. Journal of Business Research, 63, 1018-1024.

Mollen, A., \& Wilson, H. (2010). Engagement, telepresence and interactivity in online consumer experience: Reconciling scholastic and managerial perspectives. Journal of Business Research, 63(9-10), 919-925.
Morgan-Thomas, A., \& Veloutsou, C. (2013). Beyond technology acceptance: Brand relationships and online brand experience. Journal of Business Research, 66(1), 2127.

Morwitz, V. G., Steckel, J. H., \& Gupta, A. (2007). When do purchase intentions predict sales? International Journal of Forecasting, 23(3), 347-364.

Nayyar, R., \& Gupta, S.L. (2011). Determinants of Internet Buying Behavior in India. Asian Journal of Business Research,1(2),53-65.

Nepomuceno, M. V., Laroche, M., \& Richard, M. O. (2014). How to reduce perceived risk when buying online: The interactions between intangibility, product knowledge, brand familiarity, privacy and security concerns. Journal of Retailing and Consumer Services, 21(4), 619-629.

Park, J., \& Stoel , L. (2005). Effect of brand familiarity, experience and information on online apparel purchase. International Journal of Retail \& Distribution Management, 33, Issue: 2, 148-160

Park, C. (2002). A Model on the Online Buying Intention with Consumer Characteristics and Product Type. Department of Management Information Systems/ Korea University, Jochiwon, Chungnam, South Korea.

Percy, L., \& Rossiter, J. R. (1992). A model of brand awareness and brand attitude advertising strategies. Psychology \& Marketing, 9, 263-274.

Phau, I. \& Poon, S. M. (2000). Factors influencing the types of products and services purchased over the Internet, Internet research: Electronic Networking Applications and Policy, 10(2), 102-113.

Poddar, A., Mosteller, J., \& Ellen, P. S. (2009). Consumers rules of engagement in online information exchanges. Journal of Consumer Affairs, 43(3), 419-448.

Ray, S., Ow, T., \& Kim, S. S. (2011). Security Assurance: How Online Service Providers Can Influence Security Control 
Perceptions and Gain Trust. Decision Sciences, 42(2), 391-412.

Renny, G.S., \& Siringoringo, H. (2013). Perceived usefulness, ease of use, and attitude towards online shopping usefulness towards online airlines ticket purchase. Social and Behavioural Sciences, 81(2013), 212-216.

Romaniuk, J., \& Nenycz-Thiel, M. (2013). Behavioral brand loyalty and consumer brand associations. Journal of Business Research, 66(1), 67-72.

Rosa, E., Rios, Hernan, E., \& Riquelme. (2010). Sources of Brand Equity for Online Companies. Journal of Research in Interactive Marketing, 4, 3, 214-240.

Rose, S., Hair, N., \& Clark, M. (2011). Online Customer Experience: A Review of the Business-to-Consumer Online Purchase Context. International Journal of Management Reviews, 13(1), 24-39.

Ryan, G., \& Valverde, M. (2005). Waiting for service on the internet: Defining the phenomenon and identifying the situations. Internet Research, 15(2), 220-240.

Sahney, S., Ghosh, K., \& Shrivastava, A. (2013). Conceptualizing consumer trust in online buying behaviour: an empirical inquiry and model development in Indian context. Journal of Asia Business Studies, 7(3), 278-298.

Sridhar, S., \& Srinivasan, R. (2012). Social Influence Effects in Online Product Ratings. Journal of Marketing, 76(5), 7088 ,

Srinivasan, R., \& Moorman, C. (2005). Strategic Firm Commitments and Rewards for Customer Relationship Management in Online Retailing. Journal of Marketing, 69(4), 193-200.

Svatošová, V. (2013). Motivation of Online Buyer Behavior. Journal of Competitiveness, 5(3), 14-30.

Swan, J.E., Trawick, I.F., Rink, D.R., \& Roberts, J. (1988). Measuring dimensions of purchaser trust of industrial salespeople, Journal of Personal Selling and Sales Management, 8, 1-15.
Swinyard, W.R., \& Smith, S.M. (2003). Why people (dont) shop online: A lifestyle study of the Internet consumer. Psychology and Marketing, 567-597.

Szymanski, D.M., \& Hise, R.T. (2000), E-satisfaction: an initial examination. Journal of Retailing, 76(3), 309-322.

Thamizhvanan, A., \& Xavier, M. J. (2013).

Determinants of customers' online purchase intention: an empirical study in India. Journal of Indian Business Research, 5(1), 17-32.

Tsiakis, T(2012). Consumers Issues and Concerns of Perceived Risk of Information Security in Online Framework. The Marketing Strategies. Procedia - Social and Behavioral Sciences, 62, 1265-1270.

Urban, G.L., Sultan, F., \& Qualls, W.J. (2000). Placing trust at the centre of your Internet strategy, Sloan Management Review, Fall, 39-48.

Varadarajan, P.R., \& Yadav, M.S. (2002). Marketing strategy and the Internet: an organizing framework. Journal of the Academy of Marketing Science, 30(4), 296-312.

Verhagen, T., \& Van Dolen, W. (2011). The influence of online store beliefs on consumer online impulse buying: A model and empirical application. Information and Management, 48(8), 320-327.

Verhagen, T., Nauta, A., \& Felberg, F. (2013). Negative online word-of-mouth: Behavioral indicator or emotional release? Computers in Human Behavior, 29(4), 1430-1440.

Vijayasarathy, L.R., \& Jones, J.M. (2000). Intentions to shop using Internet catalogues: Exploring the effect of the product types, shopping orientations, and attitudes toward computers. Electronic Market, 10(1), 29-38.

Vimaladevi, K., \& Dhanabkaym, M. (2012). A study on the effects of online consumer reviews on purchasing decision. Prestige International Journal of Management \& IT- Sanchayan, 1(1), 91-99. 
Wang, H. (2010). Review of studies on online consumer trust. 2010 Second International Conference on Computational Intelligence and Natural Computing , 97-100.

Ward, M.R., \& Morganosky, M. (2002). Consumer acquisition of product information and subsequent purchase channel decisions. In: Baye, In: Baye, M.R (ed.), Advances in Applied Microeconomics: The Economics of the Internet and E-commerce. 11, 2002, Amsterdam: Elsevier Science.

Whan Park, C., MacInnis, D. J., Priester, J., Eisingerich, A. B., \& Iacobucci, D. (2010). Brand Attachment and Brand Attitude Strength: Conceptual and Empirical Differentiation of Two Critical Brand Equity Drivers. Journal of Marketing.

Wirtz, J., Ambtman, A. D., Bloemer, J., Horváth, C., Ramaseshan, B., Klundert, J. V. D., Canli, Z. G. (2013). Managing brands and customer engagement in online brand communities. Journal of Service Management, 24(3), 223-244.

Wolfinbarger, M., \& Gilly, M. (2001). Shopping online for freedom, control and fun. California Management Review, 43(2), 34-55.

Xinxin, Li., \& Lorin, M. H. (2010). Price Effects in Online Product Reviews:
An Analytical Model and Empirical Analysis. MIS Quarterly, 34(4), 809-831

Yali, A., \& Bayram, M. (2012). eWOM: The effects of online consumer reviews on purchasing decisions. International Journal of Internet Marketing and Advertising, 7(1), 51-64.

Yin-Chieh Hsu., Shu-Tzu Huang., \& Wei-Po Kuo. (2012). How Do Brand Beliefs Build Brand Equity in Online Retailing? The Role of Brand Love. Advances in information Sciences and Service Sciences, 4, 423-430.

Yoon, S. J. (2002). The antecedents and consequences of trust in onlinepurchase decisions'. Journal of Interactive Marketing, 16(2), 47-63.

Yu, D., \& Wang, K. (2011). On the effect of brand attitude on brand purchasing. International Conference on Management and Service Science, MASS 2011.

https://www.forrester.com/Brief+The+State + Of+Indias+Online+Retail+Market+ In+2015/fulltext/-/E-res121804

http://www.mckinsey.com/search.aspx?q=iCon sumers $\% 3 \mathrm{~A}+\mathrm{Life}+$ online

http://www.worldinternetproject.net/_files/_ Published/_oldis/ucla-internet-2001.pdf

http://www.mckinsey.com/ / media/ mckinsey\%20offices/india/pdfs/online and_upcoming_the_internets_impact_ on_india.ashx 